\title{
Penggunaan Tepung Kulit Pisang dalam Ransum terhadap Kadar Kolesterol, Vitamin A dan Profil Asam Lemak Kuning Telur Ayam Arab
}

The Effect of Banana Peel Meal usage in the Chicken Diet on Cholesterol, Vitamine A and Fatty Acid Profile of Arabian Chicken Egg Yolks

D M Suci*, R Zahera, M Sari, W Hermana

Corresponding email:

dwi.margi2@gmail.com

Departemen Ilmu Nutrisi dan Teknologi Pakan, Fakultas Peternakan, Institut Pertanian Bogor (Bogor Agricultural University/IPB University)

\section{ABSTRACT}

The aim of this research was to measure the effect of yellow corn substitution with banana peel meal as a beta-carotene and antioxidant source in the chicken diet on cholesterol, vitamin A and fatty acid profiles of egg yolk Arab chicken. The experimental design used was a completely randomized design. Data were analyzed by Analysis of Variance (ANOVA) and significant differences between the treatments were analyzed by Duncan's Multiple Range Test. Eighty pullet of Arabic chickens (19 weeks old) were randomly assigned to four treatment diets with four replications for 6 weeks of fed trials. Dietary treatments consisted of R0 (0\%) banana peel meal (TP) : 50\% yellow corn (JK) and 3 levels of yellow corn and banana peel. The composition of yellow corn and banana peel meal used R1 (20\% TP ; 30\% JK), R2 (30\% TP : 20\% JG) and R3 (40\% TP :10\% JG). The variables observed were production performance, cholesterol, vitamin A and fatty acid profile of the egg yolk. The results showed that egg yolk cholesterol levels were not significantly different compared to the control. Substitution of yellow corn with banana peel meal had increased vitamin A level up to $49 \%$ compared to the control. There was no difference in fatty acid profiles in all treatments observed. It is concluded that banana peel meal can be used to substitute $40 \%$ of yellow corn in the chicken diet and tend to increased vitamin A of egg yolk.

Key words: Arabic chicken, banana peel meal, cholesterol, fatty acid, yolk

\section{ABSTRAK}

Tujuan dari penelitian ini untuk mengukur pengaruh substitusi jagung kuning dengan tepung kulit pisang sebagai sumber beta-karoten dan antioksidan dalam ransum terhadap kadar kolesterol, vitamin A dan profil asam lemak kuning telur ayam Arab. Penelitian ini menggunakan 80 ekor ayam Arab periode produksi yang dipelihara dari umur 19 minggu sampai 25 minggu. Perlakuan terdiri dari ransum kontrol (R0) yaitu 0 $\%$ tepung kulit pisang (TP) : 50\% jagung kuning (JG) dan 3 level penggunaan tepung kulit pisang dan penggunaan jagung kuning yaitu R1 : 20\% (TP) :30\% (JG), R2 : 30\% (TP):20\% (JG) dan R3 : 40\% (TP):10\% (JG). Penelitian ini menggunakan Rancangan Acak Lengkap 4 perlakuan dan 4 ulangan. Data dianalisis keragaman, bila terdapat perbedaan nyata dilakukan Uji Duncan Multiple Range Test. Peubah yang diamati adalah kadar kolesterol, vitamin A, profil asam lemak kuning telur dan performa. Hasil penelitian menunjukkan kadar kolesterol kuning telur ayam tidak berbeda nyata dibandingkan dengan ransum kontrol. Substitusi jagung kuning dengan tepung kulit pisang menghasilkan kadar vitamin A kuning telur meningkat sampai $49 \%$ dibandingkan ransum kontrol. Profil asam lemak dari ransum yang menggunakan tepung kulit pisang didalam ransum tidak berbeda jauh dengan ransum yang menggunakan jagung sebanyak 50\%. Penggunaan tepung kulit pisang dapat mensubstitusi $40 \%$ jagung kuning dalam ransum dan cenderung menghasilkan telur yang mengandung vitamin A lebih tinggi.

Kata kunci: ayam arab, kolesterol, kulit pisang, profil asam lemak, kuning telur 


\section{PENDAHULUAN}

Ayam arab merupakan ayam petelur unggul yang berproduksi tinggi (Indra et al. 2013) yang tidak mempunyai sifat mengeram (Iskandar \& Sartika, 2008) sehingga produksi telurnya lebih tinggi dibandingkan dengan ayam kampung. Perkembangan ayam Arab sangat pesat karena mempunyai telur yang mirip dengan telur ayam kampung sehingga konsumen sangat menyukainya. Pemanfaatan telur ayam kampung di masyarakat belum sebagai telur konsumsi tetapi lebih banyak digunakan untuk meningkatkan daya tahan tubuh dengan cara dicampur ke dalam jamu. Peningkatan kualitas telur ayam Arab sebagai telur konsumsi dengan memproduksi telur yang rendah kolesterol dan tinggi vitamin A dapat memperluas pemanfaatan telur ayam Arab di masyarakat. Produksi telur yang rendah kolesterol dan tinggi vitamin A dapat dilakukan dengan membuat ransum menggunakan bahan pakan yang mengandung beta-karoten dan antioksidan tinggi. Salah satu bahan pakan yang berpotensi sebagai sumber beta-karoten dan atioksidan tinggi adalah tepung kulit pisang.

Kandungan beta-karoten kulit pisang dipengaruhi oleh kultivar tanaman pisang berkisar $49 \mu \mathrm{g} 100 \mathrm{~g}^{-1}$ $241,9 \mu \mathrm{g} 100 \mathrm{~g}^{-1}$, yang paling tinggi kadar beta-karoten pisang yang bewarna merah (Arora et al. 2008). Aryani et al. (2018) menyatakan kulit pisang mengandung ratarata karoten $0,13 \%$ dan antosianin $15,61 \%$. Kulit pisang mempunyai senyawa bioaktif dan mempunyai kapasitas antioksidan sebagai feed additive pada ayam broiler (Chueh et al. 2019) dan dapat sebagai sumber antioksidan alami dan pro vitamin A seperti karotinoid, fenolik, and senyawa amin (Pereira \& Maraschin 2015). Diperkirakan total kandungan fenolik kulit pisang tiga kali lebih tinggi dari buahnya (Pereira \& Maraschin 2015). Kulit pisang memberikan efek antioksidan yang kuat. Kulit pisang yang disuplementasi pada level rendah berpotensi sebagai aditif pakan antioksidan. (Cueh et al. 2019).

Selain kulit pisang sebagai sumber beta-karoten dan antioksidan di dalam ransum, penggunaan kulit pisang juga dapat menekan biaya ransum (Abel et al. 2015; Blandon et al. 2015) dengan mengurangi penggunaan bahan pakan lain sebagai sumber energi seperti dedak padi (Has et al. 2017) dan ransum komersial (Haryanto et al. 2016). Kulit pisang sebagai bahan pakan unggas ketersediaan sangat banyak mengingat Indonesia merupakan salah satu negara tropis yang sangat baik untuk pertumbuhan tanaman pisang dengan berbagai macam kultivar yang mempunyai nutrien yang bervariasi (Aryani et al. 2018; Diara 2018). Kulit pisang dengan berbagai kultivar mempunyai BETN berkisar $43,71 \%-59,39 \%$, serat kasar 9,65\%-16,14\% dan kandungan protein 5,15\%-7,53 \% (Aryani et al. 2018), sehingga kulit pisang dapat digunakan sebagai sumber energi selain sebagai sumber beta-karoten dan antioksidan..

Beberapa penelitian tentang penggunaan kulit pisang sebagai pengganti dedak padi $25 \%$ menghasilkan konversi ransum yang sama dengan ayam tanpa pemberian kulit pisang (Has et al. 2017) dan penggunaan hanya $10 \quad \%$ di dalam ransum ayam broiler menggantikan ransum komersial (Haryanto et al. 2016). Selain itu penggunaan kulit pisang di dalam ransum dapat menurunkan biaya produksi pada ayam broiler (Abel et al. 2015; Blandon et al. 2015).

Penelitian yang dilakukan selain untuk memproduksi telur yang rendah kolesterol dan tinggi vitamin A juga untuk mengevaluasi penggunaan tepung kulit pisang menggantikan jagung kuning yang merupakan sumber energi utama dan ransum unggas dengan penggunaan sebesar 50\%. Tujuan penelitian ini untuk mensubstitusi penggunaan jagung kuning dengan tepung kulit pisang sebagai bahan pakan sumber beta-karoten, antioksidan dan sumber energi untuk memproduksi kuning telur ayam yang rendah kolesterol, tinggi vitamin A, dan komposisi asam lemak yang baik.

\section{METODE}

\section{Ternak dan Kandang}

Ternak yang digunakan dalam penelitian ini adalah ayam Arab silver periode pullet umur 19 minggu sebanyak 80 ekor yang dialokasikan ke dalam 4 perlakuan dengan 4 ulangan secara acak. Setiap ulangan terdiri dari 5 ekor ayam arab silver. Kandang yang digunakan adalah kandang baterai. Masing-masing kandang disediakan tempat pakan dan tempat air minum.

\section{Pembuatan Tepung Kulit Pisang}

Limbah kulit pisang uli (Musa sp) yang diperoleh dari limbah pengolahan pisang aroma dan pisang goreng. Kulit pisang dipotong berukuran 3-5 cm, dijemur dengan sinar matahari selama \pm 9 jam kemudian dilakukan

Tabel 1 Kandungan nutrien dan beta-karoten tepung kulit pisang uli

\begin{tabular}{lr}
\hline Kandungan Nutrien & Jumlah \\
\hline Bahan Kering (\%) & 80,98 \\
Protein Kasar (\%) & 6,76 \\
Lemak Kasar (\%) & 1,18 \\
Serat Kasar (\%) & 11,51 \\
Bahan Ekstrak Tanpa Nitrogen (\%) & 45,48 \\
Abu (\%) & 16,05 \\
Kalsium (\%) & 0,65 \\
Fospor Total (\%) & 0,44 \\
Gross energi (kkal kg-1) & 3842 \\
Beta-karoten (mg $100 \mathrm{~g}^{-1}$ ) & 5,127 \\
\hline
\end{tabular}


pengeringan dalam oven suhu $60^{\circ} \mathrm{C}$ selama 2 hari. Kulit pisang yang sudah kering digiling halus. Tepung kulit pisang yang telah diproduksi dianalisis proksimat dan kadar beta-karoten yang hasilnya terlihat pada Tabel 1 .

\section{Ransum Perlakuan}

Ransum dibuat dari campuran konsentrat dengan bahan pakan sumber energi dan tepung kulit pisang. Konsentrat yang disusun mengandung protein 36,87\% (Tabel 2) dan campuran konsentrat dengan bahan pakan sumber energi serta kulit pisang mempunyai kadar protein $14 \%$ (Tabel 3). Tepung kulit pisang yang digunakan dalam ransum sebanyak 20\%, 30\% dan $40 \%$.

Pencampuran ransum dilakukan dengan membuat konsentrat terlebih dahulu. Setelah konsentrat dicampur secara merata, dilakukan pencampuran ransum perlakuan yang berasal dari konsentrat dan bahan sumber energi, yaitu jagung, pollard, CPO (Crude Palm Oil), dan tepung kulit pisang.

\section{Pemeliharaan dan Pengambilan Data}

Ayam Arab diberi ransum perlakuan selama 6 minggu dengan jumlah ransum yang diberikan 100 g ekor $^{-1}$ hari 1 dan air minum ad libitum. Pemberian ransum dan air minum dilakukan setiap hari. Penimbangan bobot badan ayam Arab dilakukan pada awal dan akhir pemeliharaan. Setiap hari dilakukan penimbangan bobot telur dan penimbangan pemberian serta sisa ransum untuk mengukur jumlah konsumsi ransum. Pada minggu ke-2, ke-4, dan ke-6 dilakukan pengambilan sampel untuk analisis kolesterol, vitamin A dan profil asam lemak kuning telur.

\section{Rancangan dan Analisis Data}

Perlakuan penggunaan tepung kulit pisang sebanyak 0\%, 20\%, 30\% dan $40 \%$ dan penggunaan jagung kuning

Tabel 2 Formula dan kandungan nutrien konsentrat ayam arab petelur

\begin{tabular}{lr}
\hline Bahan Pakan & Jumlah \\
\hline Bungkil Kedelai (\%) & 29 \\
Bungkil Kelapa (\%) & 11 \\
Tepung lkan (\%) & 40 \\
CaCO3 (\%) & 19 \\
Premix (\%) & 1 \\
\hline Kandungan Nutrien & 90,73 \\
\hline Bahan Kering (\%) & 36,87 \\
Protein Kasar (\%) & 4,22 \\
Lemak Kasar (\%) & 3,89 \\
Serat Kasar (\%) & 33,69 \\
Bahan Ekstrak Tanpa Nitrogen (\%) & 12,05 \\
Abu (\%) & 9,36 \\
Kalsium (\%) & 1,30 \\
Fospor Tersedia (\%) & 2,63 \\
Lisin (\%) & 0,86 \\
Metionin (\%) & 1914 \\
Energi Metabolis (kkal kg-1)
\end{tabular}

yaitu 50\%, 30\%, 20\% dan 10\%. Penggunaan CPO yang meningkat dengan meningkatnya tepung kulit pisang dalam ransum untuk mencapai kondisi isoenergi pada keempat ransum perlakuan.

Penelitian ini menggunakan rancangan acak lengkap dengan 4 perlakuan dan 4 ulangan. Data performa ayam arab, kolesterol kuning telur menggunakan analysis of variance dan jika terdapat perbedaan nyata dilanjutkan uji Duncan Multiple Range Test. Data hasil analisis profil asam lemak dan vitamin A kuning telur dianalisis secara deskriptif.

\section{Pengukuran Peubah Performa}

Performa ayam arab yang diukur adalah hen day production (\%), konsumsi ransum (g ekor ${ }^{-1}$ hari $^{-1}$ ), konversi ransum dan bobot telur.

Produksi Hen Day (\%) $=\frac{\text { Produksi telur yang dihasilkan }}{\sum \text { ayam yang ada }} \times 100$

Konversi ransum $\quad=\frac{\text { Konsumsi ransum }}{\text { Bobot telur yang diproduksi }}$

Analisis Kolesterol Kuning Telur. Pengukuran kadar kolesterol dilakukan berdasarkan metode LibermannBuchard. Sampel telur untuk analisis kolesterol di peroleh dari produksi telur minggu ke-6 dari perlakuan dimulai. Setiap perlakuan diambil sampel dari setiap 4 ulangan sehingga diperoleh 16 sampel. Telur dipecah kemudian diambil kuningnya untuk dianalisis. Sampel ditimbang sebanyak 0,2 g dan dimasukkan ke dalam tabung sentrifuse berskala 15. Kemudian ditambahkan cairan alkohol eter 3:1 sebanyak $12 \mathrm{ml}$, diaduk hingga

Tabel 3 Formula dan kandungan nutrien ransum perlakuan

\begin{tabular}{lrrrr}
\hline Bahan Pakan (\%) & R0 & R1 & R2 & R3 \\
\hline Jagung & 50 & 30 & 20 & 10 \\
Tepung Kulit Pisang & 0 & 20 & 30 & 40 \\
Pollard & 15 & 11 & 9 & 5,3 \\
CPO (Crude Palm Oil) & 5 & 9 & 11 & 13,2 \\
Konsentrat & 30 & 30 & 30 & 31,5 \\
\hline Kandungan Nutrien & & & & \\
\hline Bahan Kering (\%) & 89,78 & 89,03 & 85,33 & 86,74 \\
Protein Kasar (\%) & 15,12 & 14,56 & 14,54 & 14,43 \\
Lemak Kasar (\%) & 6,48 & 9,24 & 10,81 & 11,07 \\
Serat Kasar (\%) & 3,56 & 6,15 & 6,32 & 7,42 \\
BETN (\%) & 53,48 & 46,54 & 41,44 & 40,61 \\
Abu (\%) & 11,34 & 12,54 & 12,22 & 13,21 \\
Kalsium (\%) & 3,93 & 4,08 & 4,16 & 4,42 \\
Fospor Total (\%) & 1,26 & 1,10 & 1,03 & 0,75 \\
Fospor Tersedia (\%) & 0,46 & 0,46 & 0,46 & 0,48 \\
Lisin (\%) & 1,01 & 0,96 & 0,89 & 0,89 \\
Metionin (\%) & 0,38 & 0,34 & 0,31 & 0,30 \\
Gross Energi (kkal kg-1) & 3624 & 3766 & 3667 & 3694 \\
Energi Metabolis & 2794 & 2766 & 2752 & 2760 \\
(kkal kg-1) & & & & \\
Beta-karoten & 4,634 & 7,438 & 6,453 & 6,189 \\
(mg 100 g-1) & & & & \\
\hline
\end{tabular}

http://journal.ipb.ac.id/index.php/jurnalintp 
homogen. Larutan didiamkan sambil dikocok satu sampai dua kali selama 30 menit. Pengaduk dibilas menggunakan alkohol eter 3:1 dan disetarakan menjadi $15 \mathrm{ml}$, kemudian disentrifus dengan kecepatan $3000 \mathrm{rpm}$ selama 15 menit. Supernatan dipindahkan ke dalam gelas piala $50 \mathrm{ml}$ dan dipanaskan pada penangas air sampai kering. Ekstrak residu dilarutkan dengan 2,5 ml kloroform sedikit demi sedikit atau dicuci sebanyak dua kali dan dimasukkan ke dalam tabung reaksi $10 \mathrm{ml}$ untuk disetarakan volumenya menjadi $5 \mathrm{ml}$. Selanjutnya kolesterol standar $5 \mathrm{ml}$ (0,4 mg kolesterol dalam $5 \mathrm{ml}$ klorofrom) dimasukkan ke dalam tabung reaksi yang lain. Keduanya ditambahkan $2 \mathrm{ml}$ asetat anhidrida dan $100 \mu \mathrm{H}_{2} \mathrm{SO}_{4}$ pekat, kemudian dikocok sampai timbul warna hijau, kemudian disimpan selama 15 menit di dalam ruang gelap. Pembacaan menggunakan spektrofotometer pada panjang gelombang $420 \mathrm{~nm}$. Nilai kolesterol tersebut diperoleh dari perhitungan dengan menggunakan persamaan kurva standar kolesterol.

$$
\begin{aligned}
& \text { Kadar Kolesterol(mg 100mg-1) } \\
& \quad=[(0,214 x \text { Absorbansi Sampel })+0,005]: \frac{\text { Bobot sampel }}{10}
\end{aligned}
$$

Analisis Vitamin A Kuning Telur. Penentuan kandungan vitamin A dalam kuning telur menggunakan HPLC. Sampel yang digunakan untuk analisis sebanyak 4 sampel (setiap perlakuan satu sampel yang dikomposit dari 4 ulangan) . Prosedur analisis yang dilakukan adalah sampel ditimbang 0,5 g, kemudian dimasukkan ke dalam labu dan ditambahkan $30 \mathrm{ml}$ ethanol 95\%. Labu digoyang agar tercampur merata, kemudian dipanaskan selama 30 menit suhu $80^{\circ} \mathrm{C}$ menggunakan penangas air dan pendingin balik. Setelah selesai dipanaskan, kondensor dibilas dengan $20 \mathrm{ml}$ air. Sampel diekstrak dengan diethyl ether, kemudian sampel disaring menggunakan kertas saring berlipat untuk menghilangkan sisa air yang ada. Pelarut ekstrak vitamin diuapkan dengan menggunakan rotary evaporator. Residu dilarutkan dengan ethanol dan kemudian diinjekkan ke alat HPLC. Hasil vitamin A kuning telur akan dianalisis secara deskriptif.

Analisis Asam Lemak Kuning Telur. Sampel yang digunakan untuk analisis ini sebanyak 4 sampel, yaitu 1 sampel untuk setiap perlakuan yang dikomposit dari setiap ulangan. Telur dipecah dan diambil kuningnya untuk dianalisis. Prosedur analisis yang dilakukan adalah sampel ditimbang 0,5g, kemudian ditambahkan $\mathrm{NaOH}$ 0,5 $\mathrm{N}$ sebanyak $5 \mathrm{ml}$, setelah itu dipanaskan dalam waterbath pada suhu $80^{\circ} \mathrm{C}$ selama 20 menit, kemudian diangkat dan dibiarkan dingin. Setelah itu, ditambahkan BF3 sebanyak $5 \mathrm{ml}$, dipanaskan kembali dalam waterbath pada suhu $80^{\circ} \mathrm{C}$ selama 20 menit, kemudian didinginkan pada suhu kamar dan ditambahkan $\mathrm{NaCl}$ jenuh sebanyak 2 ml. Selanjutnya ditambahkan n-HEXAN
$2 \mathrm{ml}$, kemudian dikocok dan didiamkan, diambil fase atas (lapisan n-HEXAN), kemudian larutan siap untuk diinjekkan ke alat GC. Hasil asam lemak kuning telur akan dianalisis secara deskriptif

\section{HASIL DAN PEMBAHASAN}

\section{Kadar Beta-karoten, Serat Kasar, Lemak Kasar Ransum Perlakuan}

Tepung kulit pisang mempunyai kandungan betakaroten 5,127 mg100g-1. Kadar beta-karoten tepung kulit pisang lebih tinggi daripada jagung kuning yaitu 3,3 mg $100 g^{-1}$ (Nuraini et al. 2008). Penggunaan tepung kulit pisang yang semakin meningkat (20\%, 30\% dan 40\%) dan penggunaan jagung kuning yang semakin menurun (30\%, $20 \%$ dan $10 \%$ ) di dalam ransum menghasilkan kadar beta-karoten ransum, kadar serat kasar dan kadar lemak kasar semakin meningkat (Tabel 4). Kadar lemak kasar yang semakin tinggi juga disebabkan oleh penggunaan CPO yang semakin meningkat karena kadar energi metabolis tepung kulit pisang rendah (Diarra 2018). Kelemahan tepung kulit pisang sebagai bahan pakan unggas adalah kadar serat kasar yang tinggi yaitu $11,51 \%$ dan kadar serat kasar ransum meningkat dari 3,56\% (ransum kontrol) menjadi 7,42\%.

Pada Tabel 5 disajikan rataan konsumsi serat kasar, rataan konsumsi lemak kasar dan rataan konsumsi betakaroten. Kadar serat kasar dan lemak kasar tepung kulit pisang lebih tinggi daripada jagung kuning, sehingga konsumsi serat kasar, lemak kasar dan beta-karoten ransum perlakuan semakin meningkat dibandingkan dengan ransum kontrol (tanpa penggunaan tepung kulit pisang dan $50 \%$ jagung kuning).

\section{Kadar Kolesterol Kuning Telur Ayam}

Kadar kolesterol kuning telur ayam (Tabel 6) tidak berbeda nyata dibandingkan dengan ransum kontrol. Konsumsi serat kasar hingga 7,39 g ekor-1 $^{-1}$ ari $^{-1}$ dan konsumsi beta-karoten 7,26 mg ekor-1hari-1 belum mampu menurunkan kadar kolesterol kuning telur. Penggunaan tepung kulit pisang yang menyebabkan

Tabel 4 Kadar serat kasar, lemak kasar, dan betakaroten ransum

\begin{tabular}{crrr}
\hline Perlakuan & $\begin{array}{r}\text { Serat Kasar } \\
\text { Ransum } \\
(\%)\end{array}$ & $\begin{array}{r}\text { Lemak Kasar } \\
\text { Ransum } \\
(\%)\end{array}$ & $\begin{array}{r}\text { Beta-karoten } \\
\text { Ransum } \\
(\mathrm{mg} \mathrm{100-1} \mathrm{g})\end{array}$ \\
\hline R0 & 3,56 & 6,48 & 4,634 \\
R1 & 6,15 & 9,24 & 7,438 \\
R2 & 6,32 & 10,81 & 6,453 \\
R3 & 7,42 & 11,07 & 6,189 \\
\hline
\end{tabular}

R0 = Ransum $0 \%$ tepung kulit pisang + 50\% jagung kuning; R1 = Ransum mengandung 20\% tepung kulit pisang+ jagung kuning 30\%; R2 = Ransum mengandung 30\% tepung kulit pisang + jagung kuning 20\%; R3 = Ransum mengandung 40\% tepung kulit pisang + jagung kuning $10 \%$ 
Tabel 5 Konsumsi serat kasar, lemak kasar dan betakaroten ayam Arab

\begin{tabular}{crrr}
\hline Perlakuan & $\begin{array}{r}\text { Serat Kasar } \\
\text { Ransum } \\
(\%)\end{array}$ & $\begin{array}{r}\text { Lemak Kasar } \\
\text { Ransum } \\
(\%)\end{array}$ & $\begin{array}{r}\text { Beta-karoten } \\
\text { Ransum } \\
\left(\mathrm{mg} \mathrm{100}^{-1} \mathrm{~g}\right)\end{array}$ \\
\hline R0 & 3,24 & 6,48 & 4,22 \\
R1 & 6,00 & 9,24 & 7,26 \\
R2 & 6,13 & 10,81 & 6,25 \\
R3 & 7,39 & 11,07 & 6,17 \\
\hline R0 = Ransum 0 \% tepung kulit pisang + 50\% jagung kuning; R1 = \\
Ransum mengandung 20\% tepung kulit pisang+ jagung kuning \\
30\%; R2 = Ransum mengandung 30\% tepung kulit pisang + jagung \\
kuning 20\%; R3 = Ransum mengandung 40\% tepung kulit pisang + \\
jagung kuning10\%
\end{tabular}

kadar energi metabolis ransum menurun memerlukan peningkatan energi ransum dengan penggunaan $\mathrm{CPO}$ dalam ransum. Peningkatan penggunaan CPO di dalam ransum menyebabkan kandungan asam lemak jenuh ransum meningkat dan kandungan kolesterol kuning telur meningkat pada penelitian ini. Pada CPO terdapat empat jenis asam lemak yang mempunyai konsentrasi tinggi secara berurutan yaitu oleat, palmitat, linoleat dan stearat (Siregar et al. 2018). Crude Palm Oil mengandung asam lemak jenuh, yaitu palmitat yang cukup tinggi sebesar 46,4\% dari total asam lemak (NRC, 1994). Asam lemak palmitat mengalami beta-oksidasi, yaitu proses pemecahan asam lemak untuk diubah ke dalam bentuk energi. Asam lemak palmitat terjadi pemecahan berulang selama 7 kali, yang menghasilkan 8 molekul asetil Koa. Asetil Koa diperlukan juga untuk sintesis kolesterol. Mekanisme penurunan kolesterol cukup sulit, karena unggas akan tetap mensintesis kolesterol di dalam tubuhnya untuk memenuhi kebutuhannya. Konsumsi beta-karoten ransum 7,26 mg ekor-1 hari- $^{-1}$ belum mampu menghambat kerja enzim HMG-KoA (hidroksimetil glutaril-KoA) reduktase yang berperan penting dalam pembentukan mevalonat pada biosintesis kolesterol. Pembentukan mevalonat yang terhambat akan menghambat pembentukan skualen dan lanostreol yang akan mengalami serangkaian reaksi untuk membentuk kolesterol. Hal ini yang menyebabkan kandungan betakaroten dan serat kasar ransum yang meningkat tidak memberikan pengaruh terhadap penurunan kandungan kolesterol kuning telur. Hasil kolesterol kuning telur pada penelitian ini lebih rendah dari Rehault-Godbert \& Nys (2019) sebesar 0,939 g $100 \mathrm{~g}^{-1}$. Selain itu pada kulit pisang terdapat saponin yang dapat meningkatkan ekskresi kolesterol (Anhwange et al. 2009) tetapi pada penelitian ini tidak terdapat efek dari saponin terhadap penurunan kolesterol kuning telur.

\section{Kadar Vitamin A Kuning Telur}

Kadar vitamin A kuning telur semakin meningkat dengan meningkatnya penggunaan tepung kulit pisang dan menurunnya penggunaan jagung kuning (Tabel6).
Tabel 6 Rataan kolesterol, vitamin A dan rataan skor warna kuning telur ayam Arab

\begin{tabular}{|c|c|c|c|}
\hline Perlakuan & $\begin{array}{r}\text { Rataan } \\
\text { kolesterol } \\
\text { kuning telur } \\
\left(\mathrm{mg} 100^{-1} \mathrm{mg}\right)\end{array}$ & $\begin{array}{l}\text { Vitamin } A^{*} \\
\text { kuning telur } \\
\left(\mathrm{mg} 100^{-1} \mathrm{~g}\right)\end{array}$ & $\begin{array}{r}\text { Rataan skor } \\
\text { warna kuning } \\
\text { telur } \\
\text { (yolk color fan) }\end{array}$ \\
\hline RO & $0,558 \pm 0,042$ & 0,428 & $8,0 \pm 0,2$ \\
\hline R1 & $0,649 \pm 0,059$ & 0,433 & $7,6 \pm 0,2$ \\
\hline R2 & $0,642 \pm 0,067$ & 0,560 & $7,8 \pm 0,8$ \\
\hline R3 & $0,647 \pm 0,047$ & 0,639 & $7,7 \pm 0,5$ \\
\hline
\end{tabular}

Hasil analisis Laboratorium Terpadu Fakultas Peternakan, IPB.

*Sampel vitamin A komposit dari 4 ulangan

Perlakuan R3 (tepung kulit pisang 30\% + jagung kuning $20 \%$ dan perlakuan R4 (tepung kulit pisang 30\% dan jagung kuning $10 \%$ ) menghasilkan kadar vitamin A kuning telur meningkat sebanyak 31\%-49\% dibandingkan ransum kontrol. Kandungan vitamin A pada kuning telur dengan pemberian tepung kulit pisang lebih tinggi dibandingkan dengan Rehault-Godbert\& Nys (2019) yaitu sebesar $371 \mu \mathrm{g} 100 \mathrm{~g}^{-1}$.

Kandungan vitamin A kuning telur dipengaruhi oleh konsumsi beta-karoten. Konsumsi beta-karoten pada penggunaan tepung kulit pisang lebih tinggi dari pada ransum kontrol (Tabel 5). Beta-karoten merupakan karotenoid yang dapat berperan sebagai pro-vitamin A yang akan diubah menjadi vitamin A di dalam mukosa usus dan diserap dalam bentuk vitamin A. Beta-karoten yang dikonsumsi dipecah melalui reaksi oksidasi oleh enzim beta-karoten dioksigenase yang menghasilkan vitamin A. Konsumsi beta-karoten yang tinggi pada perlakuan R1 7,26 mg ekor-1 hari $^{-1}$ menghasilkan vitamin A yang dideposit dalam kuning telur lebih rendah dibandingkan pada perlakuan R2 dan R3 dengan konsumsi beta-karoten yang lebih rendah, yaitu $6,25 \mathrm{mg}$ ekor $^{-1}$ hari $^{-1}$ dan 6,17 mg ekor ${ }^{-1}$ hari $^{-1}$. Konversi betakaroten menjadi vitamin A tergantung dari efisiensi konversi vitamin A di dalam tubuh. Peningkatan betakaroten di ransum menyebabkan efisiensi konversi betakaroten menjadi vitamin A menurun dari rasio 2:1 menjadi 5:1 (McDowell, 2000). Hasil penelitian ini tidak sesuai dengan hasil penelitian Wiradimadja et al. 2010 semakin tinggi beta-karoten di dalam ransum akan meningkatkan kadar vitamin A pada telur.

\section{Skor Warna Kuning Telur}

Peranan beta-karoten selain berperan sebagai prekusor vitamin A, juga sebagai sumber pigmen pada kuning telur. Konsumsi beta-karoten pada penggunaan tepung kulit pisang meningkat dibandingkan dengan ransum kontrol (Tabel 5). Peningkatan beta-karoten ini karena kadar beta-karoten tepung kulit pisang lebih tinggi dibandingkan dengan jagung kuning. Beta-karoten akan disimpan dalam jaringan lemak di seluruh tubuh dan mengakibatkan warna kekuningan pada lapisan jaringan lemak, termasuk kuning telur (Sutama, 2008). 
Tabel 7 Profil asam lemak kuning telur ayam Arab

\begin{tabular}{|c|c|c|c|c|c|}
\hline Asam Lemak & Ro & R1 & $\mathrm{R} 2$ & R3 & Telur* \\
\hline Miristat (C14:0) & 0,48 & 0,49 & 0,71 & 0,39 & \\
\hline Palmitat (C16:0) & 24,84 & 24,16 & 27,99 & 26,82 & 31,7 \\
\hline Stearat (C18: 0) & 7,85 & 7,81 & 9,38 & 7,33 & 8,3 \\
\hline $\begin{array}{l}\text { ¿asam lemak } \\
\text { jenuh (\%) }\end{array}$ & 33,16 & 32,47 & 38,08 & 34,54 & 40 \\
\hline Oleat (18:1) & 4,59 & 43,68 & 41,78 & 45,33 & 42,2 \\
\hline $\begin{array}{l}\text { Linoleat } \\
(18: 2 \omega 6)\end{array}$ & 15,50 & 17,72 & 17,85 & 11,09 & 13,9 \\
\hline $\begin{array}{l}\text { Linolenat } \\
(18: 3 \omega 3)\end{array}$ & 0,41 & 0,39 & 0,27 & 0,13 & 0,3 \\
\hline $\begin{array}{l}\sum \text { asam lemak } \\
\text { tidak jenuh (\%) }\end{array}$ & 60,49 & 61,80 & 59,89 & 56,55 & 56,4 \\
\hline $\begin{array}{l}\text { Asam lemak } \\
\text { dan lain-lain (\%) }\end{array}$ & 6,34 & 5,74 & 2,03 & 8,91 & 3,60 \\
\hline$\omega 3: \omega 6$ & $\begin{array}{r}1: \\
37,72\end{array}$ & $\begin{array}{r}1: \\
44,41\end{array}$ & $\begin{array}{r}1: \\
66,59\end{array}$ & $\begin{array}{r}1: \\
88,03\end{array}$ & $\begin{array}{r}1: \\
46,30\end{array}$ \\
\hline
\end{tabular}

Hasil analisis Laboratorium Terpadu Fakultas Peternakan, IPB .

Sampel komposit dari setiap ulangan.

*) Amrullah (2004)

$\mathrm{R} 0=$ Ransum $0 \%$ tepung kulit pisang $+50 \%$ jagung kuning; $\mathrm{R} 1=$ Ransum mengandung $20 \%$ tepung kulit pisang+ jagung kuning

$30 \%$; R2 = Ransum mengandung 30\% tepung kulit pisang + jagung kuning 20\%; R3 = Ransum mengandung $40 \%$ tepung kulit pisang + jagung kuning $10 \%$

Penggunaan jagung kuning yang menurun di dalam ransum menyebabkan kandungan xantofil ransum menurun tetapi dapat digantikan oleh beta-karoten yang terdapat pada tepung kulit pisang sehingga menghasilkan skor warna kuning telur yang tidak menurun banyak (skor 7-8) (Tabel 6) sesuai dengan Wiradimadja et al. (2010)

\section{Kadar Asam Lemak Kuning Telur}

Beberapa asam lemak jenuh digunakan oleh tubuh untuk melawan virus, bakteri dan protozoa serta mendukung sistem kekebalan tubuh (Sartika 2008). Kuning telur ayam Arab memiliki asam lemak jenuh lebih rendah dibandingkan dengan asam lemak tidak jenuh (Tabel 7). Secara umum profil asam lemak dari semua perlakuan tidak berbeda jauh. Asam lemak yang paling banyak ditemukan pada kuning telur ayam Arab adalah palmitat, oleat, dan linoleat sesuai dengan Rehault-Godbert \&Nys (2019) dan Suci et al. (2017). Total asam lemak tidak jenuh tertinggi pada penggunaan 20\% tepung kulit pisang (R1) dan hanya sedikit lebih tinggi $(2,15 \%)$ dari perlakuan tanpa penggunaan tepung kulit pisang (R0). Beta-karoten yang dapat berfungsi sebagai antioksidan dapat melindungi asam lemak tidak jenuh dari oksidasi yang berlebih, sehingga dapat meningkatkan asam lemak tidak jenuh, tetapi pada penelitian ini tidak terlihat nyata peningkatan asam lemak tidak jenuh pada telur.

Asam palmitat dan asam stearate merupakan asam lemak jenuh yang dominan pada kuning telur ayam yaitu 6,04 g100 g-1 (Rehault-Godbert \&Nys, 2019). Asam lemak palmitat cenderung meningkat sebesar 7,96\% - 12,69\% pada perlakuan penggunaan 30\% tepung kulit pisang (R2) dan 40\% (R3) dibandingkan perlakuan kontrol. Asam oleat dan linoleat merupakan asam lemak tidak jenuh yang dominan pada telur, sedangkan asam lemak linolenat konsentrasinya rendah pada telur.

Penggunaan tepung kulit pisang dan CPO yang semakin meningkat cenderung menurunkan asam lemak linolenat. Selain itu rasio asam lemak linolenat dibandingkan asam lemak linoleat semakin tinggi. Rasio yang semakin meningkat karena meningkatnya asam lemak omega 6 . Asam lemak omega 6 bermanfaat untuk pertumbuhan dan perkembangan kecerdasan balita (Diana 2013). Pencegahan terhadap penyakit koroner, artritis, asma, depresi diperlukan perbandingan asam lemak omega 3 dan omega 6 sebesar 2:1 (Diana 2013). Penggunaan tepung kulit pisang dari 20\%- 40\% meningkatkan rasio asam linoleat dengan asam lemak linolenat dibandingkan ransum kontrol (37:1 vs 45:1 85:1) sedangkan menurut Rehault-Godbert \& Nys (2019) diperoleh rasio 21:1 untuk kuning telur ayam. Penggunaan CPO pada ransum ayam mempengaruhi kadar profil asam lemak jenuh dan asam lemak tidak jenuh. Peningkatan asam lemak omega 3 dan omega 6 melalui suplementasi bahan pakan tinggi omega 3 dan omega 6 berpotensi meningkatkan rasio asam lemak omega 3 dan omega 6 pada daging dan telur (Konieczka et al. 2017; Antruejo et al. 2011).

\section{Performa Ayam Arab Petelur}

Performa ayam arab petelur selama 6 minggu pemberian ransum perlakuan tercantum pada Tabel 8. Penggunaan tepung kulit pisang 20\% menghasilkan hen day production sekitar 50\% yang sama dengan ayam yang diberi ransum kontrol, sedangkan pada penggunaan tepung kulit pisang 30\%-40\% terjadi penurunan $(\mathrm{p}<0,05)$ produksi telur, walaupun konsumsi ransum meningkat $(p<0,01)$ dibandingkan ransum kontrol.

Konsumsi pakan tertinggi pada perlakuan dengan penggunaan tepung kulit pisang dalam ransum sebesar $40 \%$. Perlakuan dengan penggunaan 20\% tepung kulit pisang (R1) dapat menghasilkan produksi hen day dan berat telur yang sama dengan kontrol. Peningkatan konsumsi pakan pada perlakuan R1 menunjukkan pakan yang dibutuhkan lebih banyak untuk menghasilkan produksi hen day dan berat telur yang sama dengan kontrol. Penurunan performa pada penggunaan tepung kulit pisang 30\% dan $40 \%$ disebabkan konsumsi serat kasar dan lemak kasar ransum yang lebih tinggi (Tabel 5) dibandingkan ransum kontrol, Konsumsi serat kasar yang tinggi dalam ransum dapat mengurangi lama waktu pencernaan ransum sehingga jumlah nutrien yang dapat diserab lebih rendah (Piliang \& Djojosoebagio, 2006). Kulit pisang mempunyai beberapa anti nutrien yaitu hydrogen cyanide, oxalate, pitat tetapi yang paling tinggi adalah saponin sebesar $24 \mathrm{mg} \mathrm{kg}^{-1}$ (Anhwange et al. 
Tabel 8 Performa ayam Arab

\begin{tabular}{|c|c|c|c|}
\hline \multirow{2}{*}{ Asam Lemak } & \multicolumn{3}{|c|}{ Perlakuan } \\
\hline & $\mathrm{RO}$ & $\mathrm{R} 1$ & $\mathrm{R} 2$ \\
\hline 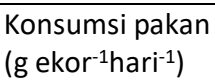 & $91,01 \pm 1,90^{A}$ & $97,64 \pm 1,10^{\mathrm{B}}$ & $96,94 \pm 0,6^{\mathrm{B}} \quad 99,73 \pm, 48^{\mathrm{A}}$ \\
\hline $\begin{array}{l}\text { Hen day } \\
\text { production (\%) }\end{array}$ & $49,27 \pm 9,02^{a}$ & $50,12 \pm 11,20^{a}$ & $32,93 \pm 8,95^{b} 31,10 \pm 0,83^{b}$ \\
\hline $\begin{array}{l}\text { Berat telur (g } \\
\text { butir-1) }^{-1} \text { ) }\end{array}$ & $36,70 \pm 0,31^{a}$ & $35,93 \pm 0,74^{a}$ & $34,87 \pm 0,98^{b} 34,00 \pm 0,93^{b}$ \\
\hline Konversi pakan & $5,11 \pm 0,92^{b}$ & $5,45 \pm 0,85^{b}$ & $8,26 \pm 2,30^{a} \quad 9,01 \pm 0,43^{a}$ \\
\hline
\end{tabular}

Superskrip yang berbeda pada baris yang sama menunjukkan berbeda nyata $(\mathrm{p}<0,05)$ dan sangat nyata $(\mathrm{p}<0,01)$

$\mathrm{R} 0=$ Ransum $0 \%$ tepung kulit pisang $+50 \%$ jagung kuning; $\mathrm{R} 1=$

Ransum mengandung 20\% tepung kulit pisang+ jagung kuning 30\%;

$\mathrm{R} 2$ = Ransum mengandung 30\% tepung kulit pisang + jagung kuning

20\%; R3 = Ransum mengandung $40 \%$ tepung kulit pisang + jagung kuning $10 \%$

2009). Saponin dapat menghambat pertumbuhan pada unggas dan babi (Anhwange et al. 2009; Azza et al. 2017). Selain itu terdapat tanin sebagai faktor anti nutrien yang utama (Diarra 2018), kulit pisang kering mengandung

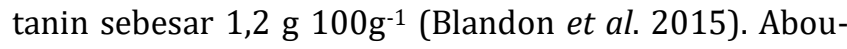
Arab \& Abu Salem (2017) kulit pisang mengandung tanin, oksalat, pitat dan hydrogen cyanide yang dapat diturunkan dengan pengeringan menggunakan microwave.

Kebutuhan energi pada perlakuan R2 dan R3 lebih banyak berasal dari CPO yang memiliki lemak kasar yang tinggi. Tingginya laju aliran ransum dalam saluran pencernaan mengakibatkan lemak bergerak melewati usus secara cepat dan menyebabkan lemak tidak dihidrolisis secara efisien. Hal ini menyebabkan berkurangnya energi yang diabsorbsi oleh tubuh dan mengakibatkan nutrien yang dibutuhkan untuk menghasilkan telur pada perlakuan R2 dan R3 berkurang, yang menyebabkan produksi telur dan berat telur juga menurun. Berkurangnya energi yang diabsorbsi menyebabkan ayam Arab petelur meningkatkan konsumsi ransum untuk memenuhi kebutuhan energi dan nutrien lainnya. Peningkatan konsumsi ransum tanpa diikuti dengan peningkatan produksi hen day dan berat telur menyebabkan konversi pakan pada perlakuan R2 dan R3 meningkat. Berdasarkan performa yang dihasilkan terlihat penggunaan tepung kulit pisang 20\% dan jagung kuning $30 \%$ (R1) menghasilkan konversi ransum yang sama dengan ransum kontrol. Mulyadi (2013) menyatakan bahwa ayam Arab umur 32 minggu menghasilkan hen day production rataan $60 \%$, konsumsi ransum 109,34 g ekor-1 hari $^{-1}$ dan konversi pakan 4,76 dengan berat telur 39\%. Indra et al. (2013) melaporkan konsumsi ayam Arab berkisar 74 g ekor-1 $^{-1}$ ari $^{-1}$ dengan bobot telur 42-46 g.

\section{SIMPULAN}

Penggunaan tepung kulit pisang dalam ransum (20\%$40 \%$ ) mensubstitusi jagung kuning dalam ransum ayam mampu meningkatkan vitamin A kuning telur 31\%-49\% dibandingkan kontrol, tetapi tidak menurunkan kolesterol. Profil asam lemak penggunaan tepung kulit pisang didalam ransum tidak berbeda jauh dengan ransum yang menggunakan jagung sebanyak 50\%. Penggunaan tepung kulit pisang untuk mensubstitusi jagung kuning dalam ransum sebanyak $40 \quad \%$ menghasilkan konversi ransum yang sama dengan kontrol.

\section{DAFTAR PUSTAKA}

Abel FAS, Adeyemi OA, Oluwole OB, Oladunmoye 00, Ayo-Ajasa OY, Anuoluwatelemi J0. 2015. Effect of treated banana peel meal on the feed efficiency, digestibility and cost effectiveness of broiler chicken diet. Journal of Veterinery Science \& Animal Husbandry. 3 (1): $1-6$

Abou-Arab AA, Abu-Salem FM. 2017. Nutritional and anti-Nutritional composition of banana peels as influenced by microwave drying methods. International Scholarly and Scientific Research \& Innovation. 11(12): 845-852

Amrullah, IK. 2004. Nutrisi Ayam Petelur. Cetakan ke-3. Bogor (ID): Lembaga Satu Gunungbudi.

Anhwange BA, Ugye TJ, Nyiaatagher TD. 2009. Chemical composition of Musa sapientum (Banana) peels. Electronic Journal of Environment, Agricultural and Food Chemistry. 8 (6):437-442

Antruejo A, Azcona J0, Garcia PT, Gallinger C, Rosmini M, Ayerza R, Coates W, Perez CD. 2011. Omega-3 enriched egg production: The effect of $\alpha$-linolenic $\omega$-3 fatty acid sources on laying hen performance and yolk lipid content and fatty acid composition. British Poultry Science. 52(6): 750-760

Aryani T, Mu'awanah IAU, Wydiantara AB. 2018. Karakteristik fisik, kandungan gizi tepung kulit pisang dan perbandingannya terhadap syarat mutu tepung terigu. Jurnal Riset Sains dan Teknologi. 2(2): 45-50

Arora A, Choudhary D, Agarwal G, Singh VP. 2008. Composition variation in $\beta$-carotene content, carbohydrate and antioxidant enzymes in selected banana cultivar. International journal of Food Science and Technology. 43: 1913-1921

Blandon JC, Hamady GAA, Abdel-Moneim A. 2015. The effect of partial replacement of yellow corn by banana peels with and without enzymes on broiler's performance and blood parameters. Journal of Animal and Poultry Science. 4(1): 10-19

Diana, FM. 2013. Omega 6. Jurnal Kesehatan Masyarakat. 7(1): 26-31

Diarra SS. 2018. Peel meals as a feed ingredient in poultry diets. Chemical composition, dietary recommendation and prospect. Journal of Animal Physiology and Animal Nutrition. 102: 12841295

Chueh CC, Lin LJ, Lin WC, Huang SH, Jan MS, Chang SC, Chung WS, Lee TT. 2019. Antioxidant capacity of banana peels and its modulation of Nrf2-ARE associated gene expression in broiler chickens. Italian Journal of Animal Science. 18 (1): 1394-1403 
Haryanto, A, Miharja K, Wijayani N. 2016. Effect of banana meal on the feed conversion ratio and blood lipid profile of broiler chickens. International Journal of Poultry Science. 15 (1) : 27-34

Has, H, Napirah A, Dewi L. 2017. Efektivitas substitusi kulit pisang dengan dedak padi dalam ransum ayam kampung. Makasar (ID): Seminar Nasional Peternakan. Universitas Hasanudin.

Indra GK, Achmanu, Nurgiatiningsih A. 2013. Performans produksi ayam Arab (Gallus turcicus) berdasarkan warna bulu. Jurnal Ternak Tropika. 14 (1): 8-14

Konieczka M, Czauderna S, Smulikowsk S. 2017. The enrichment of chicken meat with omega-3 fatty acid by dietary fish oil or its mixture with rapeseed or flaxseed-effect of feeding duration dietary fish oil, flaxseed, and repeseed and n-3 enriched broiler meat. Animal Feed Science and Technology. 223 : 42-52

McDowell, L.R. 2000. Vitamine in Animal and Human Nutrition. $2^{\text {nd }}$ Edition. Iowa (US): State University Press, Iowa.

Mulyadi Y. 2013. Penggunaan pakan fungsional terhadap performan produksi dan kualitas telur ayam arab. Jurnal Ilmu Ternak. 13 (2): $27-33$

[NRC] National Research Council. 1994. Nutrient Requirements of Poultry. 9th $^{\text {th }}$ Revised Edition. Washington. D. C. (US) : National Academy Press,

Nuraini, Sabrina, Latif SA. 2008. Performa ayam dan kualitas telur yang menggunakan ransum mengandung onggok fermentasi dengan Neurospora crassa. Media Peternakan. 31:195-202.

Pereira A, Maraschin M. 2015. Banana (Musa spp) from peel to pulp: ethnopharmacology, source of bioactive compounds and its relevance for human health. Jurnal Ethnopharmacology. 160:149-163

Piliang WG, Djojosoebagio S. 2006. Fisiologi Nutrisi. Volume I. Edisi ke2. Bogor (ID): IPB Press

Rehaul-Godbert, S, Guyot N, Nys Y. 2019. The Golden Egg: Nutritional value, bioactivities, and emerging benefits for human health. Nutrients. 11: 1-26 (www.mdpi.com/journal/nutrient)

Sartika RAD. 2008. Pengaruh asam lemak jenuh, tidak jenuh dan asam lemak trans terhadap kesehatan. Jurnal Kesehatan Masyarakat. 2(4): 154-160

Siregar HA, Rahmadi HY, Wening S, Suprianto E. 2018. Komposisi asam lemak dan karoten kelapa sawit Elaeis oleifera, interspesifik hibrida, dan Pseudo-backcross pertama di Sumatera Utara, Indonesia. Jurnal Penelitian Kelapa Sawit. 26 (2): 91-101

Suci DM, Fitria Z, Mutia R. 2017. Meat fatty acid and cholesterol content of native Indonesian Muscovy Duck Fed with rice bran in tradisional farm. Animal Production. 19 (1):37-45

Sutama, INS. 2008. Daun pepaya dalam ransum menurunkan kolesterol pada serum dan telur ayam. Jurnal Veteriner. 9: 152-156.

Wiradimadja R, Burhanuddin H, \& Saefulhadjar D. 2010. Peningkatan kadar vitamin A pada telur ayam melalui penggunaan daun katuk (Sauropus androgynus L. Merr) dalam Ransum. Jurnal Ilmu Ternak. 10 (2): 90-94 